\title{
Glances of Dietetic Oral Guar Gum: Reducing Cholesterol in Human Scenario
}

\author{
Alok Raghav ${ }^{1 *}$ and Jamal Ahmad ${ }^{2}$ \\ ${ }^{1}$ Rajiv Gandhi Centre for Diabetes and Endocrinology, JN Medical College, Aligarh Muslim University Aligarh, India \\ ${ }^{2}$ Rajiv Gandhi Centre for Diabetes and Endocrinology, JN Medical College, Aligarh Muslim University, Aligarh, India
}

Submission: April 01, 2018; Published: April 10, 2018

*Corresponding author: Alok Raghav, PhD, Rajiv Gandhi Centre for Diabetes \& Endocrinology, JN Medical College, Aligarh Muslim University, India, Tel: +919412672185; Email: alokalig@gmail.com

\begin{abstract}
Dietary oral guar gum (fiber) has various effects on cholesterol metabolism, pancreatic functions and intestinal physiological mechanisms. The hypo cholesteromic effects of this fiber are well known by studies on intestinal cholesterol absorption, fecal sterol and bile acid loss from various animal models and human clinical investigations. Apart from altering the normal physiological processes, it also affects the molecular expression of various genes as published by few workers but further investigation is needed in this area. This dietary fiber has been known to lower plasma LDL cholesterol concentrations. Fiber also elevates several enzymatic activity and intestinal response. The ability of guar gum to induce weight loss enables it to be used as weapon against patients suffering from obesity and elevated cholesterol levels.
\end{abstract}

Abbreviations: SCAP: Sterol Cleavage Activating Protein

\section{Introduction}

\section{Preface of Guar Gum}

The world agriculture produces enough food to meet the energy need of population of around 6 billion people and in pace with population growth. But worldwide the demand of adequate diet rich in nutrients especially protein is increasing with time. Guar Gum is among the nutritional substitute for protein and fibers. Guar or cluster bean (Cyamopsis tetragonoloba (L) Taub), (Fam. Leguminosae) is a drought tolerant annual leguminous plant, consisting of high molecular weight $(50,000-8,000,000)$ polysaccharides composed of galactomannans;mannose: galactose in ratio 2:1. Chemically, guar gum is a polysaccharide composed of the sugars galactose and mannose. The backbone is a linear chain of $\beta 1$, 4-linked mannose residues to which galactose residues are 1, 6-linked at every second mannose, forming short side-branches. It is primarily grown in arid and semi arid regions of Indian Subcontinent. India production contribute to $80 \%$ of the world's total production [1,2] (up to 6 million tons per year) and net export of guar seeds and guar gum (over 117000 tons) bring in over 187,380,000 US Dollars annually. In India, the tender pod of guar crop is consumed largely as a vegetable in human diet while the whole plant is good for cattle feed and as a nitrogen rich green manure. The seeds are dehusked, milled and screened to obtain the ground endosperm (native guar gum) [1]. The gum may be washed with ethanol or isopropanol to control the microbiological load (washed guar gum). It also contribute commercially in food(ice -creams, cheese, puddings), pharmaceuticals (tablet binder and disintegrating agent and in micro-encapsulation of drugs), cosmetics (emulsifier, thickner, and stabilizer in creams and skin care products, tooth pastes, shampoos, conditioners, and shaving gels/creams), and industrial applications (cloth and paper manufacture, paints, mosquito repellant coils, oil well drilling mud [3], explosives, ore flotation). Guar meal (germ and hull) is commonly used as fodder for cattle and poultry. In the U.S., differing percentages are set for its allowable concentration in various food applications [4] .In Europe; guar gum has EU food additive code E412.

\section{Structural Formula Representation of Guar Gum}

(Figure 1)

\section{Effect of Dietary Fiber on Cholesterol Metabolism}

The regulation of cholesterol metabolism by guar gum concludes that it is having hypocholesterolomic effect and serves as protective role for cardiac disorders as indicated by various clinical trial in humans. Although a number of pharmaceutical products are available to cure the risk factors [5] involved in the pathology of atherosclerotic vascular diseases [6-8], but the clinical trials of natural fibers curing these cardiac disorders 
are emerging as a landmark in the field of food nutrition and healthcare. Published data on the animal feeding studies $[9,10]$ and meta analysis reports $[11,12]$ categorize this soluble fiber as beneficial dietary supplement. Many published reports also state the regulatory role of this soluble fiber in cholesterol metabolism and reduction in circulating cholesterol concentrations [13]. Consumption of these water soluble, viscous forming fibers such as guar gum, pectin, and psyllium has consistently been shown to reduce plasma cholesterol in humans [14-17].

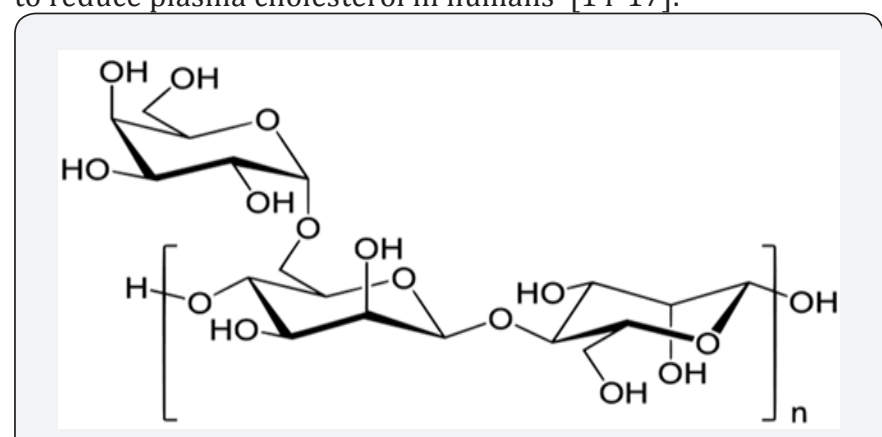

Figure 1: Structural formula representation of guar gum.

\section{How Dietary Fiber Alters the Cholesterol Level?}

It is well known that soluble fibers act in the intestine to promote secondary responses in the liver and peripheral circulation from direct effects within the intestinal lumen $[16,18]$. The fiber also reduces the dietary fat and cholesterol uptake and also decreases the cholesterol level in the intestine [19].The dietary fiber interferes with the solubilization and digestion of cholesterol. In small intestine the fiber along with the cholesterol as a result of intestinal losses migrates in the large intestine, in which the dietary fiber undergo the process of fermentation and facilitates the production of short chain fatty acids. These short chain fatty acids might be involved in the regulation of cholesterol homeostasis. The altered chylomicron composition due to interference with the dietary fiber may also be involved in the defective metabolism of cholesterol. Flowchart representation of the regulation of the cholesterol regulation by dietary fiber is shown in the Figure 2.

A compensatory increase in the expression of hepatic HMG -CoA reductase, the rate limiting enzyme in cholesterol biosynthesis, is thought to account for the reduction in the hepatic free cholesterol pool following the consumption of guar gum [20]. The production of short chain fatty acids by bacterial fermentation of the fiber in the large intestine is thought to have multiple health benefits and may be involved in mediating the hypocholesterolemic effects of dietary fiber [21].

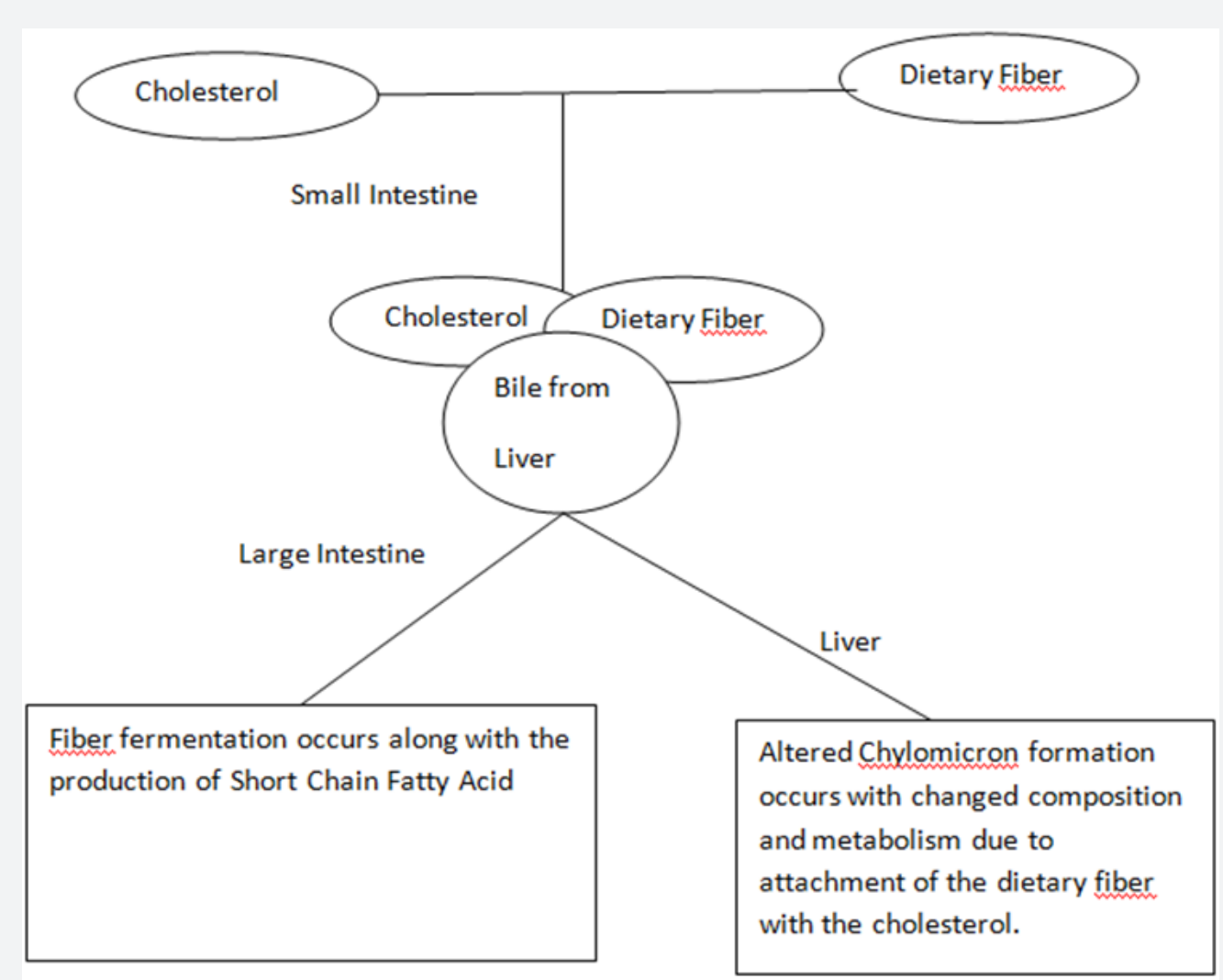

Figure 2: Flowchart representation of probable cholesterol regulation by dietary soluble fiber.

\section{Regulation of Gene Expression by Dietary Fiber}

The hypo cholesterolemic effect of guar gum encounters the regulation of the mRNA and protein expression of hepatic
LDLr, SR-B1, and SREBP2 associated with the antherogenic diet. In response to guar gum consumption, mRNA and protein expression of the hepatic LDLr were increased [22]. Nonsterol 
transcriptional regulation of the LDLr involves transcription factor early growth response in association with the sterol independent regulatory elements [23], estrodiol stimulated expression through the estrogen response element [24], and insulin stimulated expression through SREBP1a [25]. Sterol dependent transcription of the LDLr is regulated through SREBP2 [26] and more recently with the liver X receptors [27]. Few studies suggested that covertase subtilisin/kexin type 9, a proteinase regulated by SREBP2 enhances the degradation of the LDLr protein [28]. The SREBP2 regulates hepatic cholesterol metabolism by binding sterol response elements in the promoter region of a target genes [26]. Under normal physiological level of the cholesterol the SREBP2 precursor protein is found to be associated with the sterol cleavage activating protein (SCAP) in the endoplasmic reticulum. As per requirement of the cholesterol the SREBP-SCAP complex translocates to the Golgi apparatus where the transcriptionally active amino terminal domain is released by the proteolytic cleavage [29]. By the assistance of a protein factor importin $\beta$ [30], the amino terminal domain enters the nucleus and upregulates the transcription of target genes, including LDLr. Several published reports demonstrate the mechanisms associated with the hypocholesterolemic effects of dietary fibers that have pertained to the hepatic mRNA expression of HMG-CoAr and CYP7 A1 [31]. There is also increase in hepatic ATP-binding cassette transporter G5/G8 mRNA and protein expression and biliary cholesterol concentration.

\section{Intestinal and Enzymatic Response to Dietary Guar Gum Fiber}

The guar gum is rich in galactomannans and form probably a viscous gel like entity in the lumen of the intestine, stomach. When dietary fiber is consumed, on reaching to the stomach it resides in the lumen and forms an increased feeling of satiety and reduction of the appetite $[32,33]$ as it has slow rate of absorption from the lumen of intestine, these attributes could be due to the bulkiness of the guar diet. The fiber also effect on the pancreatic enzymatic activities, as its consumption elevates the total activities of amylase, lipase and protease [34]. Similar effects on food intake and body weight gain have been observed with the insoluble fiber sources [35,33]. The water retaining potential of the dietary guar gum due to its fibrous nature has contributed in making this fiber to show the result of increased weight of stomach and intestine along with the gastrointestinal tract. In addition, there is also increase in the mass of intestinal tissues, which leads to increase in weight of intestine [36]. The bulkiness and greater viscosity in the intestine could slow the diffusion of the enzymes, substrate and the product of the digestion to an absorptive surface [37].

\section{Future the Rapeutic Potential of the Guar Gum}

The future relevance of the functional fiber based foods will depend on the integrated approach of public health, researchers and doctors. Due to unique features associated with the dietary fibers such as guar gum, it serves as tool for the patients suffering from the several cardiac problems especially with atherosclerotic patients. The hypo cholesterolemic effects related with soluble fiber consumption are clear and supported by several esteemed publications around the globe. It also eradicates the obesity, which is a major problem of the developed world and arising problem of the developing world. Ahead of the physiological approach many genetic approaches have also been studied which state its role in the regulation of the gene expression engaged in the lipid metabolism. Detailed knowledge of the mechanism of lowering the plasma cholesterol level by fiber is paramount to developing novel fiber based diet that target the cholesterol reductions. It's now turn of researchers and mankind servants to contribute in this marathon and provide a precious and healthy gift to mankind.

\section{References}

1. http://www.fao.org/ag/agn/jecfa-additives/specs/monograph3/ additive-218.pdf.

2. Mishra Sourav (2008) India guar gum exports up on industry demand Reuters, India.

3. (2008) India guar futures extend losses on crude oil fall. Reuters, India.

4. Food additive list Maximum Usage Levels Permitted- Guar gum.

5. Lairon D, Arnault N, Bertrais S, Planells R, Clero E, et al. (2005) Dietary fiber intake and risk factors for cardiovascular disease in French adults. Am J Clin Nutr 82: 1185-1194.

6. McTaggart F, Buckett L, Davidson R, Holdgate G, McCormick A, et al. (2001) Preclinical and clinical pharmacology of rosouvastatin, a new 3-hydroxy-3-methlyglutaryl coenzyme A reductase inhibitor. Am J Cardiol 87(5): 28-32.

7. Sudhop T, Lutjohann D, Kodal A, Igel M, Tribble DL, et al. (2002) Inhibition of Intestinal cholesterol absorption by ezetimible in humans. Circulation 106(15): 1943-1948.

8. De Medina P, Payre BL, Bernad J, Bosser I, Pipy B, etal. (2004) Tamoxifen is a potent inhibitor of cholesterol esterification and prevents the formation of foam cells. J Pharmacol Exp Ther 308(3): 1165-1173.

9. Van Bennekum AM, Nguyen DV, Schulthess G (2005) Mechanisms of cholesterol -lowering effects of dietary insoluble fibers: relationships with intestinal and hepatic cholesterol parameters. Br J Nutr 94: 331337.

10. Venkatesan N, Devaraj SN, Devarj H (2007) A fiber cocktail of fenugreek, guar gum and wheat bran reduces oxidative modification of LDL induced by an atherogenic diet in rats. Mol Cell Biochem 294: 145-153.

11. Anderson JW, Major AW (2002) Pulses and lipaemia, short and long term effect: potential in the prevention of cardiovascular disease. Br J Nutr 88: 263-271.

12. Castro IA, Barroso L, Sinnecker P (2005) Functional foods for coronary heart disease risk reduction:a meta analysis using a multivariate approach. Am J clin Nutr 82: 32-40.

13. Fernandez ML, Wilson TA, Conde K, Vergara Jimenez M, Nicolosi RJ (1999) Hamsters and guinea pigs differ in their plasma lipoprotein cholesterol distribution when fed diets varying in animal protein, soluble fiber, or cholesterol content. J Nutr 129: 1323-1332.

14. Brown L,Rosner B, Willett WW, Sacks FM (1999) Cholesterol lowering effects of dietary fiber: a meta-analysis. Am J Clin Nutr 69: 30-42. 
15. Knopp RH, Superko HR, Davidson M, Insull W, Dujovne CA, et al. (1999) Long term blood cholesterol lowering effects of a dietary fiber supplement. Am J Prev Med 17: 18-23.

16. Schneeman BO (1999) Fiber, inulin and oligofructose: similarities and differences. J Nutr 129: 1424.

17. Butt MS, Shahzadi N, Sharif MK, Nasir M (2007) Guar Gum:a miracle therapy for hypercholesterolemia, hyperglycemia and obesity. Crit Rev Food Sci Nutr 47: 389-396.

18. Fernandez ML, Vergara Jimenez M, Conde K, Behr T, Abdel Fattah G (1997) Regulation of apolipoprotein B-containing lipoproteins by dietary soluble fiber in guinea pigs. Am J Clin Nutr 65(3): 814-822.

19. Simons LA, Gayst S, Balasubramaniam S, Ruys J (1987) Long term treatment of hypercholesterolaemia with a new palatable formulation of guar gum. Atherosclerosis 45(1): 101-108.

20. Favier ML, Bost PE, Demigne C, Rémésy C (1998) The cholesterol lowering effect of guar gum in rats is not accompanied by an interruption of bile acid cycling. Lipids 33(8): 765-771.

21. Chen WJ, Anderson JW, Jennings D (1984) Propionate may mediate the hypocholesterolemic effects of certain soluble plant fibers in cholesterol-fed rats. Proc Soc Exp boil Med 175: 215-218.

22. Todd C Rideout, Zongfei Yuan, Bakovic M, Liu Q Li RK, et al. (2006) Guar gum consumption increases hepatic nuclear SREBP2 and LDL receptor expression in pigs fed an atherogenic diet. J Nutr 137(3): 568572 .

23. Zhang F, Lin M, Abidi P, Thiel G, Liu J (2003) Specific interaction of Egr1 and c/EBPbeta leads to the transcriptional activation of the human low density lipoprotein receptor gene. J Biol Chem 278(45): 44246-44254.

24. Bruning JC, Lingohr P, Gillette J, Hanstein B, Avci H, et al. (2003) Estrogen receptors alpha and Sp1 interact in the induction of the low density lipoprotein receptors. J Steroid Biochem Mol Biol 86(2): 113121.

25. Streicher R, Kotzaka J, Muller -Wieland D, Siemeister G, Munck M, et al. (1996) SREBP-1 mediates activation of the low density lipoprotein receptor promoter by insulin and insulin like growth factor-I. J Biol Chem 271(12): 7128-7133.

26. Hua X, Yokoyama C, Wu J, Briggs MR, Brown MS, et al. (1993) SREBP-2, a second basic helix -loop -helix leucine zipper protein that stimulates transcription by binding to a sterol regulatory element. Proc Natl Acad Sci USA 90: 11603-11607.

27. Ishimoto K, Tachibana K, Sumitomo M, Omote S, Hanano I, et al. (2006) Identification of human low density lipoprotein receptor as a novel target gene regulated by liver X receptor alpha. FEBS Lett 580(20): 4929-4933.

28. Seidah NG, Khatib AM (2006) The proprotein convertase and their implication in sterol and /or lipid metabolism. Biol Chem 387(7): 871877.

29. Horton JD, Goldstein JL, Brown MS (2002) SREBPs: activators of the complete program of cholesterol and fatty acid synthesis in the liver. J Clin Invest 109(9): 1125-1131.

30. Nagoshi E, Yoneda Y (2001) Dimerization of sterol regulatory elementbinding protein 2 via the helix-loop-helix leucine zipper domain is a prerequisite for its nuclear localization mediated by importin beta. Mol Cell Biol 21(8): 2779-2789.

31. Horton JD, Cuthbert JA, Spady DK. (1994) Regulation of hepatic 7 alpha-hydroxylase expression by dietary psyllium in the hamster. J Clin Invest 93(5): 2084-2092.

32. Leeds AR, Gassull MA, Metz GL, Jenkins DJA. (1975) Food: influence of form on absorption. Lancet, pp. 1213-1215.

33. Schneeman BO, Richter BD, Jacobs LR (1982) Response to dietary wheat bran in the exocrine pancreas and intestine of rats. J Nutr 112(2): 283-286.

34. Karen S Poksay, Schneeman BO (1983) Pancreatic and intestinal response to dietary guar gum in rats. J Nutr 113(8): 1544-1549.

35. Schneeman BO, Gallaher D (1980) Changes in small intestine digestive enzyme activity and bile acids with dietary cellulose in rats. J Nutr $110(3):$ 584-590.

36. Brown RC, Kelleher J, Losowsky MS (1979) The effect of pectin on the structure and function of the rat small intestine. Br J Nutr 42(3): 357-365.

37. Sommer H, Kasper H (1980) The effect of dietary fiber on the pancreatic excretory function. Hepato-Gastroenterology 27(6): 477-483.

\section{Your next submission with Juniper Publishers will reach you the below assets}

- Quality Editorial service

- Swift Peer Review

- Reprints availability

- E-prints Service

- Manuscript Podcast for convenient understanding

- Global attainment for your research

- Manuscript accessibility in different formats

(Pdf, E-pub, Full Text, Audio)

- Unceasing customer service

Track the below URL for one-step submission

https://juniperpublishers.com/online-submission.php 